\title{
Influence of Exchange Rate on Foreign Direct Investment Inflows: An Empirical Analysis Based on Co-Integration and Granger Causality Test
}

\author{
Lan Tan $\mathbb{D}^{\mathrm{D}},{ }^{1}$ Yifan Xu $\left(\mathbb{D},{ }^{1}\right.$ and Alemayehu Gashaw ${ }^{2}$ \\ ${ }^{1}$ Zhejiang University City College, Hangzhou, China \\ ${ }^{2}$ Zhejiang University, Hangzhou, China \\ Correspondence should be addressed to Lan Tan; tanl@zucc.edu.cn and Yifan Xu; 897973434@qq.com
}

Received 30 June 2021; Revised 24 October 2021; Accepted 9 November 2021; Published 28 November 2021

Academic Editor: Anna M. Gil-Lafuente

Copyright (C) 2021 Lan Tan et al. This is an open access article distributed under the Creative Commons Attribution License, which permits unrestricted use, distribution, and reproduction in any medium, provided the original work is properly cited.

\begin{abstract}
Although it is widely recognized that Foreign Direct Investment (FDI) inflows have a dominant effect on economic growth of host countries, the determinants of FDI inflows are still unclear. Especially, about the effect of exchange rate on FDI inflow, the results reached by scholars vary across countries or regions. It is of great practical and theoretical significance to explore the influencing effects of exchange rate on FDI inflow and identify the mechanisms that underlie them in close association with regional economic characters so as to help local government implement targeted government policies to achieve sustainable FDI inflow and sustainable economic growth. For this purpose, the influencing effects and the influencing mechanisms of the exchange rate on FDI inflows are investigated for Zhejiang province, China, over 1985-2019 by employing the co-integration tests, vector error correction models, Granger causality tests, and impulse response tests. Empirical results indicate that there are long-term stable and unidirectional causal relationship between the exchange rate and FDI inflow. Continuous appreciation of RMB against USD discourages FDI inflow. The mechanism which underlies the long-term relationship is the wealth effect, rather than the cost effect or the demand effect. By contrast, in the short run, neither the exchange rate nor the three influencing mechanism has a significant impact on FDI inflow. These results suggest policy recommendations for improving FDI by accumulating human capital and improving infrastructure. These findings are also applicable for other countries or regions with similar economic characters.
\end{abstract}

\section{Introduction}

Foreign Direct Investment (FDI) refers to the investment behaviour in which the investing country uses capital for the production and operation in the host country to own part of management rights, which is one of the main forms of modern capital internationalization. In the 1980s, China opened the field of foreign direct investment. Since then, the scale of attracting foreign direct investment in China has increased rapidly. Despite the havoc and global investment contraction caused by the novel coronavirus disease (COVID-19) pandemic, the FDI inflow into China reached a record high of 999.98 billion yuan ( $\$ 154.4$ billion) in 2020, up to $19 \%$ of the global scale, surpassing the United States as the largest foreign capital inflow country [1]. FDI inflow contributes a lot to economic growth of host country in introducing advanced technology and mature management experience, also helping host country to integrate into the global market network [2-5]. Since the contribution of FDI to economic growth has been widely recognized, it is of great practical significance to further study how to promote FDI inflow in order to achieve sustainable economic growth of China. Moreover, there are significant regional differences in economy in China. Different regions have different FDI inflow structures and different determinants for FDI inflows. Therefore, it is necessary to explore the determinants of FDI inflows in close association with regional economic characteristics.

The exchange rate is an important price and the dominant determinants of FDI inflows in the open economy. 
With the reform of the RMB exchange rate system, both the flexibility and the degree of marketization of the RMB exchange rate system are increasing, resulting in the stronger impact of the RMB exchange rate on foreign investment in China. To compare the linkage between exchange rate and FDI inflow between different regions, curves are drawn for Chinese FDI inflow as a whole and for some typical provinces alone, respectively, as seen in Figures 1(a) and 1(b). It can be found that, allowing for some time lags, there is a tendency for FDI inflow to move in a manner consistent with the exchange rate in the long run, and the regional difference is obvious. So, it is of great importance to analyse the impact of exchange rate on FDI inflow in close combination with local economic characteristics so as to help local government implement targeted government policies to achieve sustainable FDI inflow and sustainable economic growth.

About the effect of exchange rate on the FDI inflow, the research is mainly carried out from the following two aspects: the estimation of the direction and magnitude of the influence and the analysis of the influencing mechanism.

The first part of the literature measures the direction and magnitude of the influence of exchange rate on the FDI inflow. The relevant research conclusions include negative effect, positive effect, no effect, and heterogeneous effect. Typical studies, which believe that the depreciation in the exchange rate can attract FDI, include the research conducted by Ahmad et al. [6], Qamruzzaman et al. [7], and Lee and Brahmasrene [8]. Other scholars believe that the two variables are positively correlated. Both the studies on the FDI inflows in Nigeria by Ogbonna [9] and Ayomitunde et al. [10] and the study on Chinese data by Gan and Xu [11] have reached this conclusion. For the third type of conclusion, Polat and Payaslıoglu [12] pointed out that exchange rates will not affect FDI inflows based on data from Turkey. Gautam et al. [13] found no causal linkage between exchange rate and FDI inflow in China. For the fourth type of conclusion, scholars hold that the estimated influence of exchange rate on FDI inflow depends on the exchange rate system, economic structure, estimation characteristics, and the modelling approach $[14,15]$. To a certain extent, the fourth type of analysis can explain the inconsistency of empirical research conclusions based on the data from different countries.

The second strand of the literature focuses on the influencing mechanisms of exchange rate on FDI inflows. Relevant theories mainly include cost effect, wealth effect, and demand effect. First, the study on cost effect can be traced back to currency regional advantage theory by Aliber [16], in which the direction of FDI flows is considered to be consistent with the direction of currency advantage. If a country has a currency advantage, the investors in this country tend to invest directly in foreign markets, causing FDI outflows. Cushman studied the direct investment in the America from Germany, France, British, and Canada, formally proposing the cost effect theory that exchange rate will affect the relative production costs of multinational companies in the host country [17]. Specifically, the depreciation of the host country currency and the appreciation of the foreign currency will reduce the relative production costs of foreign investors in the host country, including fixed costs, labour costs, and material costs. Therefore, foreign investors only need to pay less money to purchase factors of production in the host country. This phenomenon is conducive for foreign investors to expand the scale of investment in the host country, thereby promoting the inflow of FDI into the host country [18].

The second type of influencing mechanism is wealth effect. Compared with the cost effect that emphasizes the cost changes of production factors in the host country, the wealth effect focuses on the purchasing power of the foreign investors. The wealth effect is based on analysis of 13 industry data in the America from 1974 to 1987 by Front and Stein [19]. When other conditions remain unchanged, the relative wealth values of foreign investors will change with exchange rate, which also cause changes in the currency purchasing power of the same assets by foreign investors in the host country, therefore will eventually affect their foreign direct investment. Research conducted by Li and Rengifo [20] based on data from 49 countries reached similar conclusion.

The third type of influencing mechanism is the demand effect. Different from the cost effect and wealth effect, the demand effect indicates a positive effect of exchange rate on FDI inflow: when the currency of host country appreciates, their gross domestic product (GDP) measured in foreign currencies will increase, which will expand local demand and attract market-oriented FDI [21, 22].

In sum, researchers have not reached consensus, no matter in the respect of influencing effects or in the respect of influencing mechanism. The reason may be that the effect and mechanism of the exchange rate on FDI inflows largely depend on the characteristics of the local economy and on the timeframe. However, most of the previous literatures did not pay enough attention to the comparison between the long-term and short-term effects nor to the comparison among different influencing effects based on the local economic characteristics.

To enrich the related research, in this study, the FDI flowing from the U.S.A to Zhejiang province is taken as a typical case. Contrast is made between the long-term and short-term effects. Different influencing mechanisms are analysed and compared. On the one hand, since the research results about the effect of exchange rate on FDI inflow reached by scholars vary across countries or regions, it is of great theoretical significance to find out why these results are so different. Comparison between different timeframe and different mechanisms can provide an appropriate perspective for explaining these differences. On the other hand, because the conclusions based on nationwide data are not necessarily applicable for a regional economy, it is of great practical significance to analyse the specific impact effect and specific impact mechanism of exchange rate on local FDI inflow based on the characteristics of local economy, which can better guide local government to implement policies to enhance FDI inflow and promote economic growth.

The contribution of the study is as follows. First, the long-term and short-term effects of exchange rate on FDI 


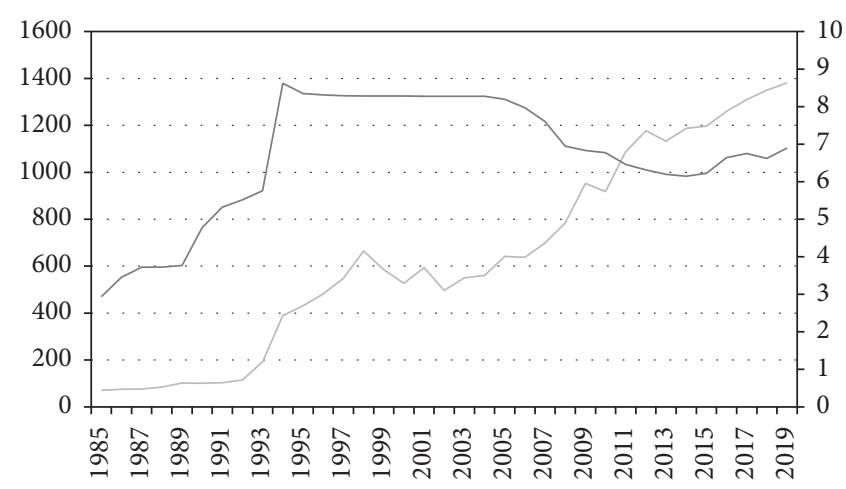

(a)

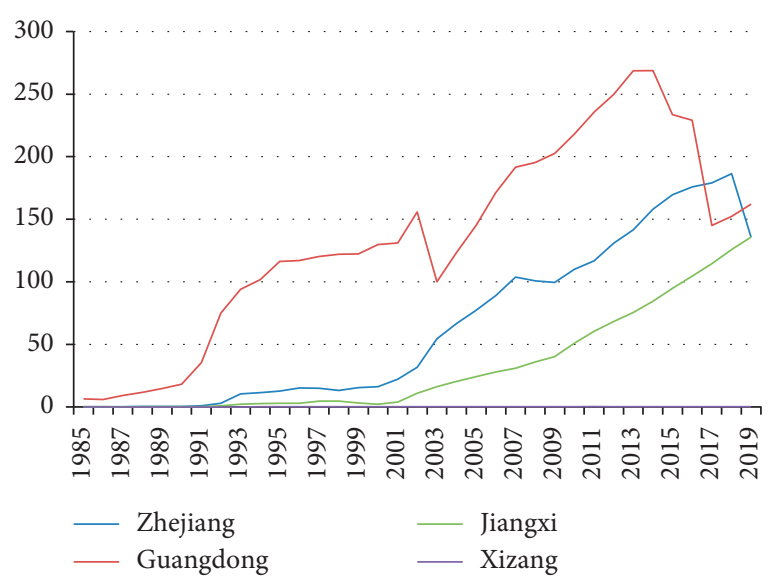

(b)

Figure 1: (a) FDI inflow in China and exchange rate. (b) FDI inflow in typical provinces. Note. (1) In Figure 1(a), the grey curve (on the left axis) represents the FDI flowing into China (unit: 100 million Chinese Yuan) and the black curve (on the right axis) represents exchange rate between USD and RMB over 1985-2019 (unit: ¥ per \$). (2) In Figure 1(b), in addition to Zhejiang (blue line), three typical provinces are selected for description, red line for Guangdong province with the highest FDI inflows, green line for Jiangxi province with the middle ranking in FDI inflows, and purple line for Xizang province with the lowest FDI inflow (unit: 100 million Chinese Yuan).

inflows are effectively distinguished, which helps to explain some of the divergences of previous research literatures. Second, this paper provides a feasible method to study the applicability of each impact mechanism for a specific economic region. The conclusions and the suggestions are scientific, feasible, and meaningful for countries and regions with similar economic characteristics.

The remaining research structure of this paper is as follows. Section 2 introduces data sources and methodology. Section 3 describes the results of the quantitative analysis. Section 4 summarizes the research and makes recommendations.

\section{Data and Methodology}

In this study, the data from Zhejiang Province, China, over 1985-2019 are used to study the effect and mechanisms of exchange rate on FDI inflows. The co-integration test and the error correction model are applied to distinguish between the long-term and short-term effects. The Granger causality test and the impulse response analysis are carried out to further determine the causality and time trend. All the three mechanism, the costs, wealth, and demand effect are tested simultaneously to make the conclusion more comprehensive. The economic characteristics of Zhejiang Province are fully considered when conducting the research and making recommendations.

Zhejiang is chosen as a typical FDI inflow region because of its high economic openness and its high proportion of FDI inflow in China, with its per capita utilization of foreign capital ranking the first in China. According to the data of 2020, as an export-oriented province, Zhejiang Province has created $6.4 \%$ of GDP and attract more than one tenth of the scale of FDI flowing into China, with only $4.57 \%$ of population and about $1 \%$ of land area in China. So, it is of typical significance to study FDI in
Zhejiang Province. The U.S.A is chosen as a typical FDI origin country for the similar reason. Even if Taiwan of China and Hong Kong of China are considered, the number of enterprises invested by the United States in Zhejiang has ranked the third for a long time. The reason for choosing the time spanning over 1985-2019 is that Zhejiang Province introduced the first foreign direct investment enterprise in 1985. Since then, the scale of FDI inflows began to rise (Figure 1(b)).

2.1. Research Variable. Three types of variables are included in the empirical analysis: dependent variable, independent variable, and control variable.

2.1.1. Dependent Variable. Following the approaches by Ahmad et al. [6], Lee and Brahmasrene [8], and Ayomitunde et al. [10], FDI inflow (USAFDI) is adopted as the dependent variable, which is measured as the FDI flowing into Zhejiang from the America in 100 million Chinese Yuan. The advantage of using the total amount instead of the proportion to GDP is that it can better reflect the overall situation of FDI inflows not just the relative situation.

2.1.2. Independent Variable. Independent variables include the exchange rate (USDCNY), the cost effect index (WAGE), the wealth effect index (GDPX), and the demand effect index (FGDPX).

(1) The Exchange Rate. The exchange rate (USDCNY) is measured as the price of RMB in units of USD. This pricing method is used internationally, which can directly reflect the changes in the nominal value of the currencies of the two countries.

(2) The Cost Effect Index. The cost effect index (WAGE) is measured as the ratio of the annual average wage of 
Zhejiang employees priced in US dollars to the average annual wage in America. The average annual wage relative to other costs, such as materials costs, is the most important cost for companies and is easy to measure. The larger the value, the higher the production cost of Zhejiang Province relative to America. Since the change of this index is partly affected by the change of exchange rate, by analysing the effect of this index, we can explore the influence of exchange rate on FDI inflow through the cost effect. This proxy was likely to discuss based on the study by Syarifuddin [18].

(3) The Wealth Effect Index. The wealth effect index (GDPX) is measured as America GDP in 100 million Chinese Yuan. Following Li and Rengifo [20], the larger the value of GDPX is, the greater the purchasing power of American investors for Zhejiang assets is. The index is highly correlated with the exchange rate. So, by analysing the effect of this index, we can explore the influence of wealth effect on FDI inflow.

(4) The Demand Effect Index. The demand effect index (FGDPX) is measured as Zhejiang GDP in 100 million US dollars. Based on Anthony and Kaz [22], Zhejiang GDP shows the scale of market demand in Zhejiang. The larger the value, the greater the market demand in Zhejiang. Since this index is also influenced by the exchange rate, by analysing the effect of this index, we can explore the demand effect of the exchange rate on FDI inflow.

2.1.3. Control Variable. Two variables such as government spending (BSGDP) and trade openness (TMX) are included as control variables.

(1) Government Spending. Government spending (BSGDP) is measured as budget surplus in Zhejiang (percentage of total GDP). According to the relevant theoretical literature, the increase in spending on infrastructure in local government, such as transportation and communication, along with the tax incentives and land price concessions given by local government to foreign companies, can directly affect the cost and income of foreign direct investment [23]. When analysing the effect of exchange rate on FDI inflow, the influence of government spending on FDI should be controlled.

(2) Trade Openness. Trade openness (TMX) is measured as total import and export in 100 million US dollars in Zhejiang. Gnangnon [24], Ali et al. [25], and Chandra and Handoyo [26] discussed the effect of trade openness on FDI inflow. When determining location, export-oriented multinational corporations prefer to be in a more open economy, to bypass the trade barriers and reduce transaction costs. So, the effect of trade openness on FDI inflow should also be controlled.
In order to eliminate the possible heteroscedasticity problem, all variables are taken as logarithms. The summary of definitions of variables is shown in Table 1.

2.2. Data Resources. The relevant data of Zhejiang including the annual average wage of Zhejiang employees (in the cost effect index), GDP of Zhejiang (in the demand effect index), government spending, trade openness, and FDI flowing into Zhejiang from America are obtained from Zhejiang Provincial Statistical Yearbook. The relevant data of America including GDP of America (in the wealth effect index) and annual average wage in America (in the cost effect index) come from the international trade database. The relevant data on exchange rate of USD to the RMB were collected from China National Statistical Yearbook.

2.3. Model Specification. Based on the previous literatures, two models are established. Following Huang et al. [23], Ali et al. [25], and Chandra and Handoyo [26], to examine the influence effect of exchange rate on FDI inflow, government spending and trade openness, along with the exchange rate, are included in the first model to help obtain an unbiased estimation for the influence of exchange rate. As seen in equation (1), the coefficient of $\beta_{1}$ measures elasticity of changes of FDI inflow to the change of exchange rate:

$$
\begin{aligned}
\ln \mathrm{USAFDI}= & \beta_{0}+\beta_{1} \ln \mathrm{USDCNY} \\
& +\beta_{2} \ln \mathrm{BSGDP}+\beta_{3} \ln \mathrm{TMX}+e_{i} .
\end{aligned}
$$

The second model puts greater emphasizes on the influencing mechanisms: the cost effect, wealth effect, and demand effect. Following Syarifuddin [18], Li and Rengifo [20], and Anthony and Kaz [22], the cost effect index, the wealth effect index, and the demand effect index, along with the exchange rate and the two control variables are included in the second model to analyse the influencing mechanisms. Adding more influencing factors into the model will help to improve the accuracy of the model and solve the problem of missing variables, so as to obtain the unbiased estimation of regression parameters. As seen in equation (2), the coefficient of $\beta_{1}$ measures the direct effect of exchange rate on FDI inflow. And the coefficient of $\beta_{2}, \beta_{3}$, and $\beta_{4}$ measures the indirect effect of exchange rate through cost changes, wealth changes, and demand changes, respectively.

$$
\begin{aligned}
\ln \mathrm{USAFDI}= & \beta_{0}+\beta_{1} \ln \mathrm{USDCNY}+\beta_{2} \ln \mathrm{WAGE} \\
& +\beta_{3} \ln \mathrm{GDPX}+\beta_{4} \ln \mathrm{FGDPX}+\beta_{5} \ln \mathrm{BSGDP} \\
& +\beta_{6} \ln \mathrm{TMX}+e_{i} .
\end{aligned}
$$

\subsection{Econometric Methodology}

2.4.1. Unit Root Test. The nonstationary of the time series may cause spurious regression. To avoid "false regression," it is essential to ascertain whether the variables are stationary. For this purpose, we apply the ADF (augmented 
TABLe 1: Summary of definitions of variables.

\begin{tabular}{|c|c|c|c|c|}
\hline & Variables & Definition & Symbol & Data resources \\
\hline $\begin{array}{l}\text { Dependent } \\
\text { variable }\end{array}$ & FDI inflow & $\begin{array}{l}\text { Foreign direct investment into Zhejiang from the } \\
\text { America (in } 100 \text { million Chinese Yuan) }\end{array}$ & USAFDI & $\begin{array}{l}\text { Zhejiang Provincial Statistical } \\
\text { Yearbook }\end{array}$ \\
\hline \multirow{4}{*}{$\begin{array}{l}\text { Independent } \\
\text { variables }\end{array}$} & $\begin{array}{l}\text { The exchange } \\
\text { rate }\end{array}$ & The price of RMB in units of USD & USDCNY & $\begin{array}{c}\text { China National Statistical } \\
\text { Yearbook }\end{array}$ \\
\hline & Cost effect index & $\begin{array}{l}\text { The ratio of the annual average wage of Zhejiang } \\
\text { employees to the annual average wage in the America } \\
\text { (both priced in US dollars) }\end{array}$ & WAGE & $\begin{array}{l}\text { Zhejiang Provincial Statistical } \\
\text { Yearbook and the international } \\
\text { trade database }\end{array}$ \\
\hline & $\begin{array}{l}\text { Wealth effect } \\
\text { index }\end{array}$ & GDP of America (in 100 million Chinese Yuan) & GDPX & The international trade database \\
\hline & $\begin{array}{l}\text { Demand effect } \\
\text { index }\end{array}$ & GDP of Zhejiang (in 100 million US dollars) & FGDPX & $\begin{array}{l}\text { Zhejiang Provincial Statistical } \\
\text { Yearbook }\end{array}$ \\
\hline \multirow{2}{*}{$\begin{array}{l}\text { Control } \\
\text { variables }\end{array}$} & $\begin{array}{l}\text { Government } \\
\text { spending }\end{array}$ & $\begin{array}{l}\text { The budget surplus in Zhejiang (percentage of total } \\
\text { GDP). }\end{array}$ & BSGDP & $\begin{array}{l}\text { Zhejiang Provincial Statistical } \\
\text { Yearbook }\end{array}$ \\
\hline & Trade openness & $\begin{array}{c}\text { Import + export (for Zhejiang, in } 100 \text { million US } \\
\text { dollars) }\end{array}$ & TMX & $\begin{array}{l}\text { Zhejiang Provincial Statistical } \\
\text { Yearbook }\end{array}$ \\
\hline
\end{tabular}

Dickey-Fuller) unit root test. Compared with the Phillips-Perron test, the errors are assumed to be independent and variance is assumed to be constant in the ADF test $[27,28]$. Due to its advantage in eliminating the influence of autocorrelation by including the first-order downward difference item at the later stage, this test method is widely used to investigate the order of integration for such variables as FDI and exchange rate $[6,8]$.

2.4.2. The Co-Integration Test. The co-integration test is used to test whether there is a long-term equilibrium relationship among multiple variables. Latif et al. argued that it is essential to adopt a reliable and robust approach for cointegration [29]. The method employed in this study is the Johansen test. The lag length of the Johansen test is confirmed by the optimal lag length of the VAR model. The result of the optimal lag length of the VAR model is determined by the AIC principle [30]. Because of the reliability of its conclusion, this test method has been widely used to measure the long-run equilibrium among many time series datasets [31-33].

2.4.3. Vector Error Correction Model. After confirmation of co-integration relationship, the vector error correction model (VECM) is applied. The reason lied in that if the cointegration relationship exists between the sequences, any temporary short-term deviation will be corrected [34]. The error correction term obtained in VECM can automatically correct the previous error, representing the speed of shortterm adjustment. For its usefulness in capturing both the long-run and short-run dynamics, this method is widely used in recent related analysis [8]. So, in this study, the VECM is adopted to determine how the deviation of shortterm fluctuation of FDI from the long-term equilibrium is corrected.

2.4.4. Granger Causality Test. Even if the co-integrated relationship is confirmed, it is uncertain whether the causality among the variables is unidirectional, bidirectional, or neutral. As one of the most feasible and classic methods [29], the Granger causality test is employed to reveal the causality between variables, as in Samour et al. [33] and Ahmad et al. [6]. In the Granger causality test, variable $X$ is considered to be the Granger cause of variable $Y$ if $Y$ can be better predicted by using data from both $X$ and $Y$ when compared with using data from $Y$ only. The optimal lag length is selected based on the Akaike information criterion (AIC). The traditional Wald test is used to estimate the direction of Granger causality.

2.4.5. The Impulse Response Analysis. Finally, the impulse response analysis is carried out to plot that the future behaviour of FDI inflow should there be a one-time shock to each endogenous variable. This method is helpful to trace the long-term dynamic relationship between variables [35]. Besides, following Lee and Brahmasrene [8], in the innovations decomposition, Cholesky transforming is used to help obtain the response of variables to independent shocks.

\section{Results and Discussion}

\subsection{Analysis on the Influencing Effects of Exchange Rate on FDI Inflows in Zhejiang}

3.1.1. Unit Root Test. To test whether the variables are stationary, the ADF test is adopted. The test results are shown in Table 2.

Results indicate that time series data for variables including $\operatorname{lnUSAFDI}$, lnBSGDP, and lnTMX are not stationary at level because $P$ values for these variables are larger than 0.05. At first difference, all variables become stationary as the $P$ values for these variables are all less than 0.05 . So, it can be concluded that all variables are integrated of order $I(1)$ and can be further used for econometric analysis.

3.1.2. Co-Integration Test. In the empirical study of this part, the lag period of the Johansen test is determined by the optimal lag period obtained in the VAR model. The specific results are shown in Table 3. 
TABLe 2: ADF test.

\begin{tabular}{lcc}
\hline Variables & ADF test $(P)$ & Stationarity \\
\hline $\ln$ USAFDI & 0.2514 & Unsteady \\
lnUSDCNY & 0.0034 & Steady \\
lnBSGDP & 0.6178 & Unsteady \\
$\ln$ TMX & 0.9949 & Unsteady \\
DlnUSAFDI & 0.0007 & Steady \\
DlnUSDCNY & 0.0004 & Steady \\
DlnBSGDP & 0.0033 & Steady \\
DlnTMX & $\leq 0.001$ & Steady \\
\hline
\end{tabular}

TABLE 3: VAR lag order selection criteria.

\begin{tabular}{lcccccc}
\hline Lag & LogL & LR & FPE & AIC & SC & HQ \\
\hline 0 & -43.90431 & NA & 0.000286 & 3.193621 & 3.380447 & -253388 \\
1 & 86.73425 & 217.7309 & $1.39 e-07$ & -4.448950 & -3.514818 & -4.150113 \\
2 & 125.9489 & 54.90050 & $3.15 e-08$ & -5.996593 & $-4.315156^{*}$ & -5.458687 \\
3 & 136.4957 & 11.95303 & $5.37 e-08$ & -5.633045 & -3.204303 & -4.856070 \\
4 & 150.8500 & 12.44039 & $8.61 e-08$ & -5.523332 & -2.347285 & -4.507287 \\
5 & 195.6855 & $26.90129^{*}$ & $2.62 e-08^{*}$ & $-8.445698^{*}$ & -3.522345 & $-6.190584^{*}$ \\
\hline
\end{tabular}

When the lag period of VAR is 5, the AIC value of VAR is the minimum according to the AIC principle. Therefore, the optimal lag period of VAR should be selected as 5 phases, and in the subsequent co-integration relationship test, the number of lag periods selected is 4 phases.

According to the previous test, there is a stationary relationship between the four variables. Therefore, a cointegration test can be carried out to test whether there is a long-term equilibrium relationship between these variables. The test results are shown in Table 4.

According to the results of the statistical test, in the case of null hypothesis "None," "Most1," "Most2," and "Most3," $P \leq 0.001, P \leq 0.001, P=0.0014$, and $P=0.0392$, respectively. Therefore, at the significance level of 0.05 , these null hypotheses are rejected, which mean that there are at least four co-integration relationships among the four variables and a long-term equilibrium relationship between them.

The standardized co-integration equation is as follows:

$$
\begin{aligned}
\ln \mathrm{USAFDI}= & 1.333841 \ln \mathrm{USDCNY}-1.449725 \ln \mathrm{BSGDP} \\
& +3.741736 \ln \mathrm{TMX}, \\
t= & (3.21909)(0.83657)(0.62674) .
\end{aligned}
$$

Through this co-integration relationship, it can be known that $\operatorname{lnUSAFDI}$ and $\operatorname{lnUSDCNY}$ are positively correlated in the long-term, which means when the RMB depreciates, the FDI inflow will increase. The exchange rate of USD to CNY changes 1\%, and the FDI inflow changes $1.34 \%$. These results are consistent with conclusions supporting the negative long-term relationship between currency value of host country and FDI inflow, by Ahmad et al. [6], Qamruzzaman et al. [7], and Lee and Brahmasrene [8]. In another word, depreciation of domestic currency is conductive for FDI inflow in the long run.
3.1.3. Vector Error Correction Model. The above co-integration test showed that there is a long-term stable equilibrium relationship between InUSAFDI and InUSDCNY. Next, the short-term equilibrium relationship between the variables is tested by the vector error correction model, which connects the short-term behaviour of the variables with the long-term change relationship. The structure of the vector error correction model is as follows:

$$
\begin{aligned}
\Delta \ln \text { USAFDI }= & \beta_{0}+\beta_{1} \Delta \ln \text { USDCNY }+\beta_{2} \Delta \ln \text { BSGDP } \\
& +\beta_{3} \Delta \ln \mathrm{TMX}+\gamma \mathrm{et}_{t-1}+e_{i} .
\end{aligned}
$$

et $_{t-1}$ is the error correction term, which is generated as the residual of equation (3). Its coefficient $\gamma$ represents the adjustment strength when short-term fluctuation deviates from its long-term equilibrium.

The estimation result of the vector error correction model is as follows:

$$
\begin{aligned}
\Delta \ln \text { USAFDI }= & -0.014656+0.630766 \Delta \ln \text { USDCNY } \\
& +0.028934 \Delta \ln \text { BSGDP }+0.754459 \Delta \ln \text { TMX } \\
& -0.207271 \mathrm{et}_{t-1}+e_{i}, \\
t= & (-0.278047)(0.566549)(1.267871) \\
& (2.435534)(-0.835503) \\
R^{2}= & 0.221131, \\
\text { S.E }= & 0.229050, \\
F= & 1.916407, \\
\text { DW }= & 1.7445178 .
\end{aligned}
$$

The estimated coefficient of error term et $t_{t-1}$ is -0.207271 , which reflects the correction of deviation. Yet, 
TABLE 4: Co-integration test.

\begin{tabular}{|c|c|c|c|c|}
\hline Hypothesized no. of CE(s) & Eigenvalue & Trace statistic & 0.05 critical value & Prob. \\
\hline None & 0.843686 & 108.8294 & 47.85613 & $\leq 0.001$ \\
\hline Most1 & 0.609719 & 53.15263 & 28.79707 & $\leq 0.001$ \\
\hline Most2 & 0.497958 & 24.92598 & 15.49471 & 0.0014 \\
\hline Most3 & 0.132200 & 4.253827 & 3.841466 & 0.0392 \\
\hline
\end{tabular}

the coefficient of error term et $t_{t-1}$ is not significant because the $t$-value of this variable is only -0.835503 , indicating that when the short-term fluctuation deviates from the long-term equilibrium, the reverse correction mechanism is not tenable. The $t$-value of $\Delta \operatorname{lnUSDCNY}$ is 0.566549 , which indicated that the change in the exchange rate has no significant impact on the FDI inflow in the short term. This short-term results are similar to research studies conducted by Polat and Payaslıoglu [12] and Gautam et al. [13], who also reached an inconclusive short-term results in case of Turkey and China.

When compared with the co-integration relationship revealed in equation (3), it can be concluded that exchange rate has a significant role in influencing FDI inflow in the long run, not the short run. The reason for this result is that the FDI flowing into Zhejiang can be classified as long-term investment behaviour, not short-term arbitrage behaviour. The main purpose for capital to flow into Zhejiang is to generate long-term returns through production and operation. Although FDI inflow may include some disguised portfolio investment, this kind of portfolio investment inflows are substantially restricted in Zhejiang. Therefore, the short-term impact of exchange rate changes on FDI inflows to Zhejiang is not significant.

3.1.4. Granger Causality Test. The Granger causality test is performed on variables to determine if there is a Granger causality relationship between variables. The results are shown in Table 5.

When the assumption is that $\ln U S D C N Y$ does not Granger cause lnUSAFDI, $P=0.0132<0.05$. Therefore, the null hypothesis can be rejected, which means that the exchange rate is the Granger reason for the FDI inflow. When the assumption is that lnUSAFDI does not Granger cause $\operatorname{lnUSDCNY}, P=0.6742>0.05$. Therefore, the null hypothesis is not rejected, which means that the FDI inflow is not the Granger cause of the exchange rate. In short, there is a unidirectional causal relationship: the exchange rate is the Granger cause for FDI inflow and not the contrary.

This result differs from that of Gautam et al. [13] who found no causal connection between exchange rate and FDI inflow in case of China. One possible reason for the different results lies in that the result of no causal connection is based on data from 1981 to 2013. By contrast, the time spanning in this study is over 1985-2019. With the market-oriented reform of the RMB exchange rate system, the price signal function of exchange rate is gradually enhanced, so it became the Granger reason affecting the inflow of FDI in recent years.
TABle 5: Granger causality test.

\begin{tabular}{lccc}
\hline Lags: & & & \\
\hline $\begin{array}{l}\text { Null hypothesis } \\
\text { lnUSDCNY does not Granger cause }\end{array}$ & 31 & 4.04016 & 0.0132 \\
$\begin{array}{l}\text { lnUSAFDI } \\
\text { lnUSAFDI does not Granger cause }\end{array}$ & 31 & 0.58875 & 0.6742 \\
$\begin{array}{l}\text { lnUSDCNY } \\
\text { lnBSGDP does not Granger cause }\end{array}$ & 31 & 0.53685 & 0.7102 \\
$\begin{array}{l}\text { lnUSAFDI } \\
\text { lnUSAFDI does not Granger cause }\end{array}$ & 31 & 5.92156 & 0.0022 \\
$\begin{array}{l}\text { lnBSGDP } \\
\text { lnTMX does not Granger cause }\end{array}$ & 31 & 0.80655 & 0.5342 \\
$\begin{array}{l}\text { lnUSAFDI } \\
\text { lnUSAFDI does not Granger cause }\end{array}$ & 31 & 1.06328 & 0.3981 \\
lnTMX & & &
\end{tabular}

3.1.5. Impulse Response Analysis. The impulse function graph of lnUSAFDI with lnUSDCNY which is varying by one standard deviation as shown in Figure 2. After giving a positive impact on $\ln U S D C N Y$ at the beginning, lnUSAFDI rises slightly in the first phase until it reached the highest level in the fifth phase and then subsides. Our outcome is parallel to the results of Lee and Brahmasrene [8] who employed monthly data and suggested that, over time, the impact of exchange rate on FDI inflows will first become larger and then gradually subsided to zero.

\subsection{Analysis on the Influence Mechanism of Exchange Rate on FDI Inflows in Zhejiang}

3.2.1. Unit Root Test. Table 6 indicates that the null hypothesis of a unit root cannot be rejected at level except for variables of $\ln U S D C N Y$ and $\operatorname{lnGDPX}$. However, at the firstorder difference, all null hypotheses of a unit root are rejected at the significance level of 0.05 , which means that all variables are integrated of order I(1) and can be further used for econometric analysis.

3.2.2. Co-Integration Test. As shown in Table 7, when the lag period of $\mathrm{VaR}$ is 3, the AIC value of $\mathrm{VaR}$ is the minimum according to the AIC principle. Therefore, the optimal lag period of VAR should be selected as 3 phases, and in the subsequent co-integration relationship test, the number of lag periods selected is 2 phases.

According to the co-integration test, there is stationary relationship between the seven variables. Therefore, the cointegration test can be carried out to test whether there is a 


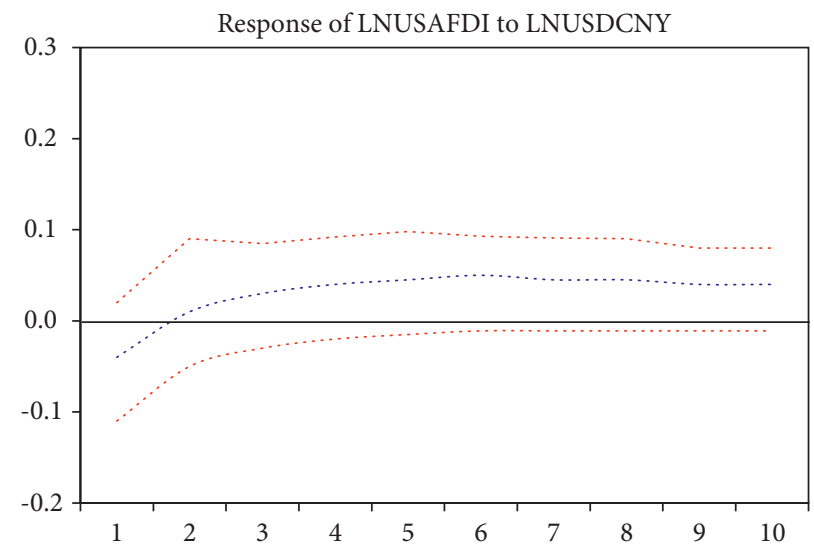

FIgURE 2: Pulse response test (red line represents the confidence interval; blue line represents the actual value).

TABLE 6: ADF test.

\begin{tabular}{lcc}
\hline Variables & ADF test (P) & Stationarity \\
\hline $\ln$ USAFDI & 0.2514 & Unsteady \\
lnUSDCNY & 0.0034 & Steady \\
lnWAGE & 0.9946 & Unsteady \\
lnGDPX & 0.0037 & Steady \\
$\operatorname{lnFGDPX}$ & 0.9383 & Unsteady \\
$\ln$ lnX & 0.9949 & Unsteady \\
$\ln$ BSGDP & 0.6178 & Unsteady \\
DlnUSAFDI & 0.0007 & Steady \\
DlnUSDCNY & 0.0004 & Steady \\
DlnWAGE & 0.0387 & Steady \\
DlnGDPX & 0.0009 & Steady \\
DlnFGDPX & 0.0001 & Steady \\
DlnTMX & $\leq 0.001$ & Steady \\
DlnBSGDP & 0.0033 & Steady \\
\hline
\end{tabular}

TABLE 7: VAR lag order selection criteria.

\begin{tabular}{|c|c|c|c|c|c|c|}
\hline Lag & $\log L$ & LR & FPE & AIC & SC & HQ \\
\hline 0 & 129.0383 & NA & $1.15 e-12$ & -7.627392 & -7.306762 & -7.521112 \\
\hline 1 & 380.7174 & 377.5187 & $3.91 e-18$ & -20.29484 & -17.72980 & -19.44460 \\
\hline 2 & 493.5322 & $119.8658^{*}$ & $1.17 e-19$ & -24.28326 & -19.47382 & -22.68907 \\
\hline 3 & 597.7142 & 65.11373 & $1.89 e-20^{*}$ & $-27.73214^{*}$ & -20.67828 & -25.39398 \\
\hline
\end{tabular}

long-term equilibrium relationship between these variables. The test results are shown in Table 8.

According to the test results, for the null hypothesis of "None," "Most1," "Most2," "Most3," "Most4," and "Most5," the corresponding $\mathrm{p}$ values are less than 0.001 , less than 0.001 , equal to 0.0024 , equal to 0.0148 , and equal to 0.0483 , respectively. Therefore, at the significance level of 0.05 , these null hypotheses are rejected, which means that there are at least five co-integration relationships among the seven variables and a long-term equilibrium relationship between them. The standardized co-integration equation is as follows:

$$
\begin{aligned}
\ln \mathrm{USAFDI}= & 2.304339 \ln \mathrm{USDCNY}+17.38693 \ln \mathrm{WAGE}+5.079269 \ln \mathrm{GDPX} \\
& -0.911169 \ln \mathrm{FGDPX}-1.739458 \ln \mathrm{BSGDP}+2.673937 \ln \mathrm{TMX} \\
t= & (2.47596)(1.15991)(2.40963)(0.23500)(0.20578)(0.09461) .
\end{aligned}
$$

Based on this co-integration relationship, it can be known that lnUSAFDI is positively and significantly correlated with both $\operatorname{lnUSDCNY}$ and $\ln$ GDPX in the long run.
When USDCNY and GDPX increase by $1 \%$, USAFDI increases by $2.304339 \%$ and $5.079269 \%$, respectively. It can be inferred that, when USD appreciates against RMB, it can not 
TABle 8: Co-Integration test.

\begin{tabular}{|c|c|c|c|c|}
\hline Hypothesized no. of CE(s) & Eigenvalue & Trace statistic & 0.05 critical value & Prob. \\
\hline None & 0.944857 & 235.4577 & 125.6154 & $\leq 0.001$ \\
\hline At most 1 & 0.862471 & 145.6250 & 95.75366 & $\leq 0.001$ \\
\hline At most 2 & 0.632136 & 84.12343 & 69.81889 & 0.0024 \\
\hline At most3 & 0.526759 & 53.12216 & 47.85613 & 0.0148 \\
\hline At most 4 & 0.436289 & 29.92947 & 29.79707 & 0.0483 \\
\hline At most5 & 0.226467 & 12.15983 & 15.49471 & 0.1494 \\
\hline At most6 & 0.126691 & 4.199447 & 3.841466 & 0.0404 \\
\hline
\end{tabular}

only influence FDI inflow directly but also influence FDI inflow indirectly through its effect on purchasing power of American multinational companies. The wealth effect holds. However, LnWAGE and lnFGDPX do not have significant effects on lnUSAFDI in the long run. So, the cost effect and the demand effect do not hold.

This result is consistent with Froot and Stein [19] and Li and Rengifo [20] in which the exchange rate has a significant impact on FDI inflows through the wealth effect in the long term. When USD appreciated against the RMB, the U.S. companies have larger purchasing power. They will be more active in looking for investment opportunities. In addition, Zhejiang Province is very attractive for foreign investors due to its favourable business environment and its superior geographical location. Therefore, when the purchasing power of foreign investors increases, the FDI inflow will increase accordingly.

In addition, our result also indicates that the exchange rate will not affect FDI inflows in Zhejiang Province through cost changes, which contradicts the cost effect hypothesis supported by Cushman [17] and Syarifuddin [18]. The reason may be related to the industrial structure of FDI flowing into Zhejiang. For example, in 2019, the FDI flowing into the primary industry, secondary industry, and the tertiary industry in Zhejiang Province was US\$19 million, 4.68 billion, and 8.8608 billion, respectively. The tertiary industry accounted for $65.34 \%$, occupying a dominant position. Moreover, in the tertiary industry, FDI into Zhejiang Province mainly flows into the computer service and software industries and leasing and business service industries. Companies conducting FDI in these industries pay more attention to the quality of labour, instead of the labour costs. Therefore, the decline in production and operating costs caused by the devaluation of RMB is not attractive enough to promote more FDI flowing into Zhejiang.

Meanwhile, our result does not confirm the demand effect hypothesis supported by Anthony and Kaz [22]. The reason may lie in that the demand effect hypothesis is more adaptable for market-oriented FDI inflow, in which the multinational corporations make direct investment in host countries in pursuit for big potential market of host country. However, this is not the case for Zhejiang province. Following Zheng and Jing [36], the index of the proportion of export to the total value of industry output has been used as a criterion to differentiate between export-oriented FDI and market-oriented FDI. For Zhejiang, this proportion is much higher (in 2019, about 31\%) than for China on average (in 2019, about 16\%). So, it can be indicated that for Zhejiang province, its local market demand is not a driven force for the FDI inflow.

3.2.3. Vector Error Correction Model. The structure of the vector error correction model is as follows:

$$
\begin{aligned}
\Delta \ln \text { USAFDI }= & \beta_{0}+\beta_{1} \Delta \ln \text { USDCNY }+\beta_{2} \Delta \ln W A G E \\
& +\beta_{3} \Delta \ln \text { GDPX }+\beta_{4} \Delta \ln \text { FGDPX } \\
& +\beta_{5} \Delta \ln \mathrm{BSGDP}+\beta_{6} \Delta \ln \mathrm{TMX}+\gamma e \mathrm{t}_{t-1}+e_{i} .
\end{aligned}
$$

The estimation result is as in the following equation:

$$
\begin{aligned}
\Delta \ln \text { USAFDI }= & -0.178605+7.902172 \Delta \ln \text { USDCNY }-2.149683 \Delta \ln \text { WAGE }+8.016928 \Delta \ln \text { GDPX148 } \\
& +2.017647 \Delta \ln \text { FGDPX }+0.011172 \Delta \ln \text { BSGDP }+0.569358 \Delta \ln \text { TMX }-0.987441 \text { et }_{t-1}+e_{i}, \\
t= & (-1.555300)(-1.537115)(1.503072)(1.692658)(1.531953)(0.573310)(2.194106)(-4.021131), \\
R^{2}= & 0.545169, \\
\text { S.E }= & 0.189093, \\
F= & 4.280777, \\
\text { DW }= & 1.502443 .
\end{aligned}
$$

The error term et $t_{t-1}$ is significant statistically, with $t$-value equals -4.021131 . The estimated coefficient of error term et $t_{t-1}$ is -0.987441 , between the normal intervals $(-1,0)$, indicating that the reverse correction mechanism works if FDI inflow deviates from the long-term equilibrium level in the short term, it will be adjusted back in the long term. The nonequilibrium 
error of the previous period et $t_{t-1}$ corrected the FDI inflow of the current period at a rate of $98.7 \%$, which is relatively strong. So, through the error correction mechanism, the relationship between these variables can quickly return to the track of longterm equilibrium relationship.

The $t$-values of the cost effect, wealth effect, and demand effect indexes are $-1.503072,1.692658$, and 1.531953 , respectively, which indicated that, in the short term, the cost effect, wealth effect, and demand effect have insignificant effects on the FDI flowing into Zhejiang Province from America.

When combined with the co-integration relationship revealed in equation (6), it can be inferred that although the wealth effect has a significant role in influencing FDI inflow in the long run, it takes time for this effect to work, so the promoting effect of wealth effect on FDI inflows is not significant in the short run. Moreover, the cost and the demand effect do not work no matter in the long term or in the short term. This result can give a further explanation for the inconclusive short-term influence of exchange rate on FDI flowing into China reached by Polat and Payaslıoğlu, and Gautam et al. $[12,13]$.

3.2.4. Granger Causality Test. The Granger causality test is performed on variables to determine whether there is a Granger causality relationship between variables. In this part, we focus on the results of the three influencing mechanisms.

The Granger causality analysis (Table 9) shows that lnWAGE and lnFGDPX do not Granger cause lnUSAFDI, while the lnGDPX is the Granger cause for LnUSAFDI. Therefore, it can be concluded that for Zhejiang, the exchange rate influences the FDI inflow mainly through the wealth effect, not from the cost and the demand effect. Our findings are similar to Froot and Stein for the U.S. [19] and Li and Rengifo for 49 countries [20].

3.2.5. Impulse Response Analysis. Finally, the impulse response analysis is carried out on the variable of wealth effect, and the result is shown in Figure 3.

Figure 3 indicates the impulse response of lnUSAFDI when lnGDPX changes by one standard deviation. With an initial positive change of lnGDPX, lnUSAFDI rises gradually in the first three phased, achieves the highest level in the third phase, and then begins to subside. This impulse response analysis result can be used as a useful supplement to the research on wealth effect by Li and Rengifo [20].

\section{Conclusion and Policy Recommendations}

This study examines the influencing effect and influencing mechanism of the exchange rate on the FDI inflow in Zhejiang using time series data over 1985 to 2019. The cointegration test and the vector error correction models are applied to analyse the long-run and short-run relationships. The Granger causality test and the impulse response analysis are carried out to further determine the causality and time trend. Three main conclusions are drawn.
TABLE 9: Granger causality test.

\begin{tabular}{lccc}
\hline Lags: 2 & & & \\
\hline $\begin{array}{l}\text { Null hypothesis } \\
\text { lnUSDCNY does not Granger cause }\end{array}$ & 33 & 3.34533 & 0.0498 \\
lnUSAFDI & $\begin{array}{c}\text { F- } \\
\text { statistic }\end{array}$ & Prob. \\
$\begin{array}{l}\text { lnUSAFDI does not Granger cause } \\
\text { lnUSDCNY }\end{array}$ & 33 & 1.30270 & 0.2878 \\
$\begin{array}{l}\text { lnWAGE does not Granger cause } \\
\text { lnUSAFDI }\end{array}$ & 33 & 0.80538 & 0.4570 \\
$\begin{array}{l}\text { lnUSAFDI does not Granger cause } \\
\text { lnWAGE }\end{array}$ & 33 & 5.24916 & 0.0116 \\
$\begin{array}{l}\text { lnGDPX does not Granger cause } \\
\text { lnUSAFDI }\end{array}$ & 33 & 4.07879 & 0.0279 \\
$\begin{array}{l}\text { lnUSAFDI does not Granger cause } \\
\text { lnGDPX }\end{array}$ & 33 & 4.80375 & 0.0161 \\
$\begin{array}{l}\text { lnFGDPX does not Granger cause } \\
\text { lnUSAFDI }\end{array}$ & 33 & 0.67776 & 0.5159 \\
$\begin{array}{l}\text { lnUSAFDI does not Granger cause } \\
\text { lnFGDPX }\end{array}$ & 33 & 2.55569 & 0.0956 \\
$\begin{array}{l}\text { lnBSGDP does not Granger cause } \\
\text { lnUSAFDI }\end{array}$ & 33 & 0.34178 & 0.7134 \\
$\begin{array}{l}\text { lnUSAFDI does not Granger cause } \\
\text { lnBSGDP }\end{array}$ & 33 & 5.52530 & 0.0095 \\
$\begin{array}{l}\text { lnTMX does not Granger cause } \\
\text { lnUSAFDI } \\
\text { lnUSAFDI does not Granger cause }\end{array}$ & 33 & 0.34703 & 0.7098 \\
lnTMX & 33 & 0.20909 & 0.8126 \\
\hline & & &
\end{tabular}

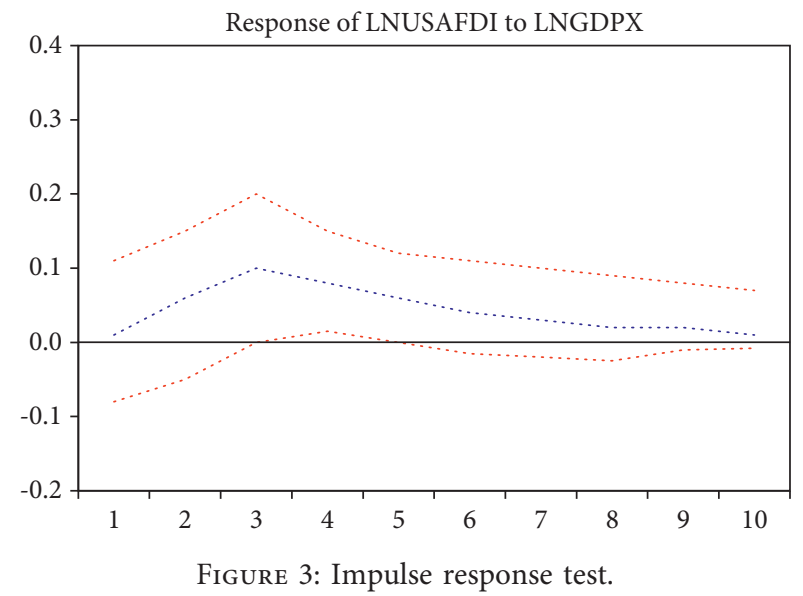

First, Zhejiang economy benefits from depreciation of $\mathrm{RMB}$ in the long run. When the RMB depreciates, the FDI flowing into Zhejiang Province from America will increase. Their long-term stable relationship is confirmed by the cointegration test, and their unidirectional causal relationship is confirmed by the Granger causality test.

Second, the long-term stable relationship between exchange rate and FDI inflow can be well explained by the wealth effect, rather than the cost effect and the demand effect. This result is also confirmed by the co-integration test and the Granger causality test. It indicates that multinational companies pay more attention to their worldwide purchasing power, rather than the labour costs or market demand of host countries in case of Zhejiang. 
Third, in the short run, neither the exchange rate nor the three influencing mechanism has a significant impact on FDI inflow. Both the results of the vector error correction models and the results of impulse response analysis have indicated it. This may be due to the strict capital controls in short-term portfolio investment inflow.

These findings have substantive and practical significance for policy makers and decision makers. On the one hand, due to the inconclusive short-term results of exchange rate on FDI inflow, policymakers and enterprise managers need not overreact to the normal short-term fluctuation of exchange rate, as long as China still implements strict capital controls. The argument is also supported by Lee and Brahmasrene [8].

On the other hand, based on the results of significant negative long-term influence of the appreciation of the RMB on FDI inflow, along with continuous appreciation of the RMB against the US dollar in recent years, Zhejiang is facing challenges about how to stabilize the inflow of FDI, so as to maintain sustainable economic growth in the future. In the light of this situation, local government should put more emphasis on the accumulation of human capital and the improvement of infrastructure. The reason lies in that the wealth effect, which has been confirmed by our studies, indicates that, when multinational corporations make more investment worldwide, they focus more on investment environment and production capacity, rather than production costs or local market demand. So, broadening the international appeal by improving the investment environment can be an efficient way to offset the adverse effects of exchange rate appreciation on FDI inflow. This argument is similar to Ahmad et al. [6].

This study differs from the previous ones in the three aspects. First, our result supports unidirectional causal relationship between exchange rate and FDI inflow, which differs from the no causal results by Gautam et al. [13]. This difference provides an evidence for the higher degree of marketization of the RMB exchange rate system. Second, our study compares the long-term with short-term effect, which can help policy makers and corporate managers to make more informed decisions. Third, most previous studies have used total amount of FDI in the whole country as the research object, but for a big country, like China, the influence of exchange rate may be "averaged" to become insignificant due to huge regional differences. So, taking a specific region as an example will help to reach more accurate conclusions and draw more targeted policy recommendations.

It is worth noting that our results are based on the economic characteristics of Zhejiang province. For some countries or regions, who have similar characters, such as strict capital control, export-oriented FDI, and FDI dominated by the tertiary industry, these results are instructive. However, for other countries or regions, these conclusions cannot be applied directly. Yet, the research methods adopted in this paper are also applicable to help find out the long-term and short-term influence effect and influence mechanism for each different region.

Finally, there is room for further discussion on this topic. Due to data availability and space limitation, this study just discusses FDI from the U.S. If FDI from other origin countries is also analysed, the conclusion will be more comprehensive. Moreover, the cost effect, the demand effect, and the wealth effect are just the three of the influencing mechanisms. There are more mechanisms that underlie the influencing effect of exchange rate on FDI inflow, such as the expected appreciation effect [37]. So, future research is expected to be carried out to explore more influencing mechanisms and use more data from other origin countries to make the analysis more comprehensive.

\section{Data Availability}

The relevant data of annual average wage of Zhejiang employees (in the cost effect index), GDP of Zhejiang (in the demand effect index), government spending, trade openness, and FDI flowing into Zhejiang from America are obtained from Zhejiang Provincial Statistical Yearbook. The relevant data of GDP of America (the wealth effect index) and annual average wage in America (in the cost effect index) come from the international trade database whereas the relevant data on exchange rate of USD to the RMB were collected from China National Statistical Yearbook. The data are also available from the corresponding author upon reasonable request.

\section{Conflicts of Interest}

The authors declare that there are no conflicts of interest regarding the publication of this article.

\section{Acknowledgments}

This work was supported by the Research Center of Digital Transformation and Social Responsibility Management and Academy of Digital Finance, ZUCC, Hangzhou, China.

\section{References}

[1] United Nations Conference on Trade and Development (UNCTAD), Global Investment Trend Monitor, No. 38, United Nations Conference on Trade and Development (UNCTAD), Geneva, Switzerland, 2021, https://unctad.org/webflyer/ global-investment-trend-monitor-no-38\#tab-2.

[2] X. W. Tian, V. I. Lo, and M. Song, "The "insider" and "outsider" effects of FDI technology spillovers: some evidence," Journal of Developing Areas, vol. 50, no. 5, pp. 1-12, 2016.

[3] G. Philip, Y. H. Jin, and W. Robert Reed, "Did FDI really cause Chinese economic growth? A meta-analysis," World Development, vol. 90, pp. 242-255, 2017.

[4] S. Luo, Y. X. Shi, Y. Sun, Z. Zhao, and G. Zhou, "Can FDI and ODI two-way flows improve the quality of economic growth? Empirical evidence from China," Applied Economics, vol. 53, no. 44, pp. 5028-5050, 2021.

[5] A. Abdulsalam, H. Xu, W. Ameer et al., "Exploration of the impact of China's outward foreign direct investment (FDI) on economic growth in Asia and North Africa along the belt and road (B\&R) initiative," Sustainability, vol. 13, no. 4, pp. 16-23, 2021.

[6] F. Ahmad, M. U. Draz, and S. C. Yang, "China's economic development: does exchange rate and FDI nexus matter?" 
Asian-Pacific Economic Literature, vol. 33, no. 2, pp. 81-93, 2019.

[7] M. Qamruzzaman, S. Karim, and J. Wei, "Does asymmetric relation exist between exchange rate and foreign direct investment in Bangladesh? Evidence from nonlinear ARDL analysis," The Journal of Asian Finance, Economics and Business, vol. 6, no. 4, pp. 115-128, 2019.

[8] J. W. Lee and T. Brahmasrene, "Exchange rate movements and structural break on China FDI inflows," Contemporary Economics, vol. 14, no. 2, pp. 112-126, 2020.

[9] B. Ogbonna, "Bounds test approach to co-integration and causality between foreign investment inflows and exchange rates dynamics in Nigeria," Journal of Humanities and Social Science, vol. 24, no. 1, pp. 49-60, 2019.

[10] A. T. Ayomitunde, A. B. Ganiyu, S. G. Matthew, and Y. A. Bako, "The determinants of foreign direct investment inflows in Nigeria: an empirical investigation," Acta Universitatis Danubius, vol. 16, no. 3, pp. 131-142, 2020.

[11] X. D. Gan and Q. Q. Xu, "Regional investment real exchange rate, FDI and economic growth (in Chinese)," World Economy Studies, vol. 4, pp. 3-15, 2020.

[12] B. Polat and C. Payaslıoğlu, "Exchange rate uncertainty and FDI inflows: the case of Turkey," Asia-Pacific Journal of Accounting \& Economics, vol. 23, no. 1, pp. 112-129, 2016.

[13] S. Gautam, V. Chadha, and R. K. Malik, "Inter-linkages between real exchange rate and capital flows in BRICS economies," Transnational Corporations Review, vol. 12, no. 3, pp. 219-236, 2020.

[14] W. Moraghen, B. Seetanah, and N. Sookia, "Explaining heterogeneity in the effect of the exchange rate and exchange rate volatility on foreign direct investment: a meta-analysis approach," African Development Review, vol. 31, no. 3, pp. 275-291, 2019.

[15] L. Chang, J. Li, K. C. Cheong, and L. Goh, "Can existing theories explain China's outward foreign direct investment in belt and road countries," Sustainability, vol. 13, no. 3, pp. 1-17, 2021.

[16] R. Z. Aliber, A Theory of Foreign Direct Investment, MIT Press, Cambridge, MA, USA, 1970.

[17] D. O. Cushman, "Real exchange rate risk, expectations, and the level of direct investment," The Review of Economics and Statistics, vol. 67, no. 2, pp. 297-308, 1985.

[18] F. Syarifuddin, "The dynamics of foreign direct investment and exchange rates: an interconnection approach in ASEAN," Munich Personal RePEc Archive, vol. 12, no. 1, pp. 1-28, 2020.

[19] K. A. Froot and J. C. Stein, "Exchange rates and foreign direct investment: an imperfect capital markets approach," Quarterly Journal of Economics, vol. 106, no. 4, pp. 1191-1217, 1991.

[20] Y. Li and E. W. Rengifo, "The impact of institutions and exchange rate volatility on China's outward FDI," Emerging Markets Finance and Trade, vol. 54, no. 12, pp. 2778-2798, 2018.

[21] F. G. Giuseppe, L. Luca, and T. Alessandro, "Trade costs, FDI incentives, and the intensity of price competition," International Journal of Economic Theory, vol. 10, no. 4, pp. 371-385, 2014.

[22] C. Anthony and M. Kaz, "Export versus FDI: learning through propinquity," International Journal of Economic Theory, vol. 16, no. 4, pp. 361-379, 2020.

[23] Z. Huang, C. Shang, and Y. Chen, "Space panel model construction of the correlation between FDI and local economic policy based on high dimensional data regression analysis," Journal of Intelligent and Fuzzy Systems, vol. 35, no. 3, pp. 3077-3089, 2018.
[24] S. K. Gnangnon, "Multilateral trade liberalisation and foreign direct investment inflows," Economic Affairs, vol. 37, no. 1, pp. 66-84, 2017.

[25] S. Ali, Z. Yusop, S. R. Kaliappan, and L. Chin, "Dynamic common correlated effects of trade openness, FDI, and institutional performance on environmental quality: evidence from OIC countries," Environmental Science and Pollution Research, vol. 27, no. 11, pp. 11671-11682, 2020.

[26] T. A. Chandra and R. D. Handoyo, "Determinants of foreign direct investment in 31 Asian countries for the 2002-2017 period," Contemporary Economics, vol. 14, no. 4, pp. 563-578, 2020.

[27] D. A. Dickey and W. A. Fuller, "Likelihood ratio statistics for autoregressive time series with a unit root," Econometrica, vol. 49, no. 4, pp. 1057-1071, 1981.

[28] P. C. B. Phillips and P. Perron, "Testing for a unit root in time series regression," Biometrika, vol. 75, no. 2, pp. 335-346, 1988.

[29] Z. Latif, Y. Mengke, Danish et al., "The dynamics of ICT, foreign direct investment, globalization and economic growth: panel estimation robust to heterogeneity and crosssectional dependence," Telematics and Informatics, vol. 35, no. 2, pp. 318-328, 2018.

[30] S. Johansen, "Statistical analysis of cointegration vectors," Journal of Economic Dynamics and Control, vol. 12, no. 2, pp. 231-254, 1988.

[31] S. Naseem, G. L. Fu, and V. ThaiLan, "Macroeconomic variables and the Pakistan stock market: exploring long and short run relationship," Pacific Business Review International, vol. 11, no. 7, pp. 621-672, 2019.

[32] X. M. Liu, Z. Latif, and S. K. Saddozai, "Mean-VaR portfolio: an empirical analysis of price forecasting of the shanghai and Shenzhen stock markets," Journal of Information Processing Systems, vol. 15, no. 5, pp. 1201-1210, 2019.

[33] A. Samour, A. Z. Isiksal, and T. Turgut, "The economic growth, energy, trade, FDI, exchange rate, and $\mathrm{CO}_{2}$ emissions in Turkey. Fresh evidence from combined co-integration test," International Journal of Ecology \& Development, vol. 36, no. 2, pp. 43-57, 2021.

[34] C. Sulaiman and A. S. Abdul-Rahim, "The relationship between $\mathrm{CO}_{2}$ emission, energy consumption and economic growth in Malaysia: a three-way linkage approach," Environmental Science and Pollution Research, vol. 24, no. 32, pp. 25204-25220, 2017.

[35] L. Mensah, E. B. Yiadom, and R. Dziwornu, "Does Eurobond issuance influence FDI location? Evidence from sub-Saharan Africa," African Journal of Economic and Management, vol. 12, no. 2, pp. 336-355, 2021.

[36] X. R. Zheng and L. Jing, "Impact of RMB exchange rate on different types of FDI: from the perspective of the product export ratio, regional and industry difference," Nanjing Business Review, vol. 46, no. 2, pp. 1-24, 2019.

[37] H. Y. Liu and I. Deseatnicov, "Exchange rate and Chinese outward FDI," Applied Economics, vol. 48, no. 51, pp. 4961-4976, 2016. 